\title{
A REAL-TIME QUANTITATIVE ASSAY FOR HEPATITIS B DNA VIRUS (HBV) DEVELOPED TO DETECT ALL HBV GENOTYPES
}

Roberta SITNIK(1), Ângela PAES(2), Cristovão Pitangueira MANGUEIRA(1,3) \& João Renato Rebello PINHO(1,4)

\begin{abstract}
SUMMARY
Hepatitis B virus (HBV) is a major cause of chronic liver disease worldwide. Besides genotype, quantitative analysis of HBV infection is extensively used for monitoring disease progression and treatment. Affordable viral load monitoring is desirable in resource-limited settings and it has been already shown to be useful in developing countries for other viruses such as Hepatitis C virus (HCV) and HIV. In this paper, we describe the validation of a real-time PCR assay for HBV DNA quantification with TaqMan chemistry and MGB probes. Primers and probes were designed using an alignment of sequences from all HBV genotypes in order to equally amplify all of them. The assay is internally controlled and was standardized with an international HBV panel. Its efficacy was evaluated comparing the results with two other methods: Versant HBV DNA Assay 3.0 (bDNA, Siemens, NY, USA) and another real-time PCR from a reference laboratory. Intra-assay and inter-assay reproducibilities were determined and the mean of CV values obtained were 0.12 and 0.09 , respectively. The assay was validated with a broad dynamic range and is efficient for amplifying all $\mathrm{HBV}$ genotypes, providing a good option to quantify HBV DNA as a routine procedure, with a cheap and reliable protocol.
\end{abstract}

KEYWORDS: HBV DNA quantification; Real Time PCR; Hepatitis B virus; Viral load.

\section{INTRODUCTION}

Hepatitis B virus (HBV) is a major cause of chronic liver disease worldwide. This virus is a small DNA virus with a partially doublestranded $3.2 \mathrm{~kb}$ genome and has been classified into eight genotypes (A-H) based on sequence divergence over the entire genome ${ }^{16-18}$. These genotypes have a distinct and well established geographic distribution ${ }^{15}$ and impact disease prognosis and progression. In Brazil, genotypes A, $\mathrm{D}$ and $\mathrm{F}$ are the most prevalent, but genotypes B, C, E and $\mathrm{G}$ have also been reported ${ }^{3,5,23,25,26}$.

Besides genotype, the quantitative analysis of HBV DNA is extensively used for monitoring disease progression and treatment of HBV infection. Commercial assays are available for quantification of HBV DNA, such as the Versant HBV DNA Assay 3.0 (bDNA - Siemens Medical Solutions Diagnostics, Tarrytown, NY, USA) with a dynamic range from 2 X $10^{3}$ to 1 X $10^{8}$ copies $/ \mathrm{mL}^{30}$ and the Amplicor HBV Monitor

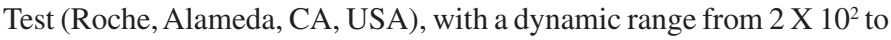
2 X $10^{5}$ copies $/ \mathrm{mL}^{11}$. Recently, several real-time PCR-based HBV DNA quantification assays have also been developed with the advantages of increased sensitivity, broader linearity and less carryover contamination risks ${ }^{1,13,20}$. Real time PCR based kits for HBV detection have also been launched by diagnostic companies and are currently replacing former HBV DNA amplification kits, such as the COBAS TaqMan 48 real-time
PCR system (Roche Molecular Systems, Branchburg, NJ), and the Abbott Real Time HBV Quantification kit (Abbott Laboratories, USA) 2,9,28.

Affordable viral load monitoring is desirable in resource-limited settings and it has already been shown to be very useful in developing countries for the Hepatitis $\mathrm{C}$ virus (HCV) and HIV ${ }^{7,8,22,24,27}$. In this paper, we describe the validation of a real-time PCR quantitative assay (qPCR) for HBV DNA based on TaqMan technology and MGB probe, which have a large dynamic range and can amplify all known HBV genotypes.

\section{MATERIALS AND METHODS}

Patients and clinical samples: For initial standardization, two international HBV reference plasmas developed by BBI Diagnostics (West Bridgewater, MA, USA) were used: PHD801 (concentration of $4.3 \times 10^{6} \mathrm{IU} / \mathrm{mL}$ diluted from 1 to 500,000X, genotype A) and QHD701 (concentration of $1.19 \times 10^{6} \mathrm{IU} / \mathrm{mL}$ diluted from one to $15,000 \mathrm{X}$, genotype A).

Clinical samples stored at $-80{ }^{\circ} \mathrm{C}$ were obtained from 95 patients from other studies. The study protocol conforms to the ethical guidelines of the 1975 Declaration of Helsinki as reflected in a priori approval by the Ethical Committee from Hospital Israelita Albert Einstein, São Paulo, SP, Brazil. Written informed consent was obtained from each patient in the study.

(1)Departamento de Patologia Clínica, Hospital Israelita Albert Einstein, São Paulo, SP, Brasil.

(2) Departamento de Estatística, Hospital Israelita Albert Einstein, São Paulo, SP, Brasil.

(3) Laboratório de Patologia Clínica, Departamento de Patologia, Faculdade de Medicina, Universidade de São Paulo, São Paulo, SP, Brasil

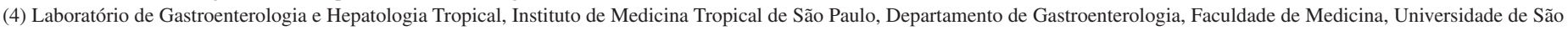
Paulo, São Paulo, SP, Brasil

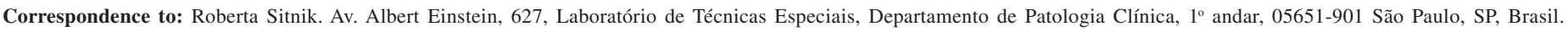
Phone: ++55 11 37472105, Fax: ++55 113747 2420, E-mail: rositnik@ hotmail.com 


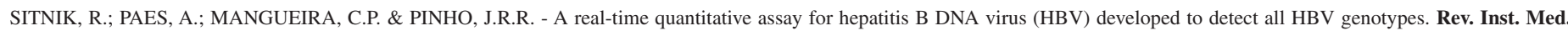
Trop. Sao Paulo, 52(3):119-24, 2010.

HBV genotypes had already been determined as previously described $^{25}$ and samples representing genotypes A, B, C, D, E and F were chosen to verify the detection of them with the new assay. Genotype distribution was: A - 36.1\%; B - 2.8\%; C - 25.0\%; D - 25.0\%; E - 2.8\% and $\mathrm{F}-8.3 \%$. For specificity analysis, samples obtained from 40 healthy blood donors provided by the Hospital Albert Einstein Blood Bank were assayed. These samples were seronegative for $\mathrm{HBsAg}$, anti-HBc, anti$\mathrm{HCV}$, anti-HIV, Treponema pallidum and Trypanosoma cruzi.

Primers and probe design: The PCR primers and probe were designed in order to equally amplify all known HBV genotypes. In this way, an alignment with sequences of all HBV genotypes described in a previous study with Brazilian patients ${ }^{25}$ and sequences from GenBank was carried out and a well conserved region among all genotypes in the $\mathrm{S}$ gene was selected. After this, PCR primers and TaqMan MGB probe sequences were checked concerning base composition, melting temperatures, GC content, internal folding using Primer Express software (Applied Biosystems, Foster City, CA, USA).

DNA extraction: For the isolation of HBV DNA from plasma, the QIAamp DNA mini kit (QIAGEN, Hilden, Germany) was used, following manufacturer's instructions. DNA was extracted from $200 \mu \mathrm{L}$ plasma with $1 \mu \mathrm{L}$ of the internal control (1X IPC DNA; Applied Biosystems, Foster City, CA, USA) and eluted in $50 \mu \mathrm{L}$ buffer.

HBV quantification by versant HBV DNA assay: The Versant HBV DNA Assay version 3.0 (bDNA - Siemens Medical Solutions Diagnostics, Tarrytown, NY, USA) was performed in accordance with the manufacturer's protocol.

Real-Time PCR assay (qPCR): Amplification was performed in a $50 \mu \mathrm{L}$ reaction mixture containing: 1X TaqMan Universal PCR Master Mix, $20 \mu \mathrm{M}$ of each primer and probe, and $5 \mu \mathrm{L}$ of extracted DNA. All samples were performed in duplicate. As an internal control, we used the TaqMan Exogenous Internal Positive Control Reagents kit with 1X IPC Mix (primers and TaqMan probe labeled with VIC) and 1X IPC DNA. All reagents were obtained from Applied Biosystems (Foster City, CA, USA).

Absolute quantification of HBV DNA was performed with ABI PRISM 7500 Real Time (Applied Biosystems, Foster City, CA, USA). Amplification starts with an incubation at $50{ }^{\circ} \mathrm{C}$ for two min for uracil $\mathrm{N}$ '-glycosylase inactivate possible contaminating amplicons, followed by 10 min at $95^{\circ} \mathrm{C}$ that activates AmpliTaq Gold Polymerase and inactivates uracil N'-glycosylase. PCR cycling program consisted of 45 two-step cycles of $15 \mathrm{~s}$ at $95^{\circ} \mathrm{C}$ and $60 \mathrm{~s}$ at $60{ }^{\circ} \mathrm{C}$ (universal conditions).

For validation of the method, qPCR assay for HBV DNA was first validated using two international HBV reference plasmas developed by BBI Diagnostics (West Bridgewater, MA, USA): PHD801 (concentration of $4.3 \times 10^{6} \mathrm{IU} / \mathrm{mL}$ diluted from one to $500,000 \mathrm{X}$, genotype A) and QHD701 (concentration of $1.19 \times 10^{6} \mathrm{IU} / \mathrm{mL}$ diluted from one to $15,000 \mathrm{X}$, genotype A). Afterwards, linearity of the test was also performed with samples of genotype D and F.

qPCR results were also compared with one other available assay: Versant HBV DNA Assay version 3.0 (bDNA - Siemens Medical Solutions Diagnostics, Tarrytown, NY, USA) $(\mathrm{n}=58)$ and samples were also sent to a reference laboratory (Quest diagnostics, San Juan
Capistrano, CA, USA) $(n=56)$. The method used in this test is real-time $\mathrm{PCR}$ of the precore/core region of the HBV genome. It has a linear range from $10^{2}$ to $5 \times 10^{9} \mathrm{IU} / \mathrm{mL}$ and was developed by Quest Diagnostics Nichols Institute (San Juan Capistrano, CA, USA)

Inter- and intra-assay reproducibilities were examined using two clinical samples (A - 7.25 log IU/mL, Genotype C; and B - $7.40 \log$ IU/ $\mathrm{mL}$, Genotype A) at different dilutions. Detection limit was established by testing samples of the most common genotypes found in Brazil (A, D and $\mathrm{F})$ in different concentrations $(20,50,100$ and $150 \mathrm{IU} / \mathrm{mL})$.

Preparation of standard: One sample with a very high viral load (6.27 $\log \mathrm{IU} / \mathrm{mL}$, genotype C) was selected and diluted in normal plasma to be used as a quantification standard. This diluted sample was frozen at $-80{ }^{\circ} \mathrm{C}$ in $200 \mu \mathrm{L}$ aliquots in order to preserve its viral load. It was then tested in triplicate using the international panel as a quantification control, and the obtained result was compared to the external reference laboratory and bDNA. In every routine, this sample was extracted, diluted from $10^{-1}$ to $10^{-6}$ and used as a quantification control.

Statistical analysis: Validation of qPCR was analyzed by scatter, Bland-Altman plots ${ }^{4}$ and linear regression. Intercept was not considered in order to evaluate the slope of fitted line. For reproducibility analyses, viral loads were summarized by means of standard deviations (SD) and coefficient of variation (CV). Scatter and Bland-Altman plots were also used to compare qPCR with other methods. Pearson's correlation coefficients were computed. All analyzes were performed using Excel and SAS statistical package, version 9.01.

\section{RESULTS}

Primers and probe design: After alignment of sequences previously described in the GenBank, conserved regions in the $S$ gene region of HBV DNA were selected and analyzed by Primer Express software (Applied Biosystems, Foster City, CA, USA), considering the best fitted combination of primers and probe.

The selected sequences are: Primer forward: 5' CCT GGY TAT CGY TGG ATG TGT 3' Primer Reverse: 5' GGA CAV ACG KGC AAC ATA CCT T 3' Probe: 5' 6FAM CTA TGC CTC ATC TTC TT MGB NFQ 3'

PCR product is $116 \mathrm{bp}$ and position of primers and probe on reference HBV strains of different genotypes is shown in Fig. 1.

Validation with international panels: The $\log _{10}$ values of all international HBV reference plasmas samples were plotted against expected results and regression analysis (without intercept) showed that the slope approached 1.0 with $\mathrm{R}^{2}=0.996$ (Fig. 2A). Bland-Altman plot shows most of points are within $95 \%$ limits of agreement (Fig. 2B).

Results of genotypes A, D and F samples diluted at different viral load levels showed that the test had a linear range from 50 to $1 \mathrm{X} 10^{8}$ $\mathrm{IU} / \mathrm{mL}$, or 1.70 to $8.0 \mathrm{log} \mathrm{IU} / \mathrm{mL}$. Samples below $50 \mathrm{IU} / \mathrm{mL}$ could be detected, but not every time tested, and detection limit was established as $50 \mathrm{IU} / \mathrm{mL}$, with $92 \%$ confidence interval. Samples with viral loads higher than $10^{8} \mathrm{IU} / \mathrm{mL}$ had results below the expected, and must be diluted (data not shown). 


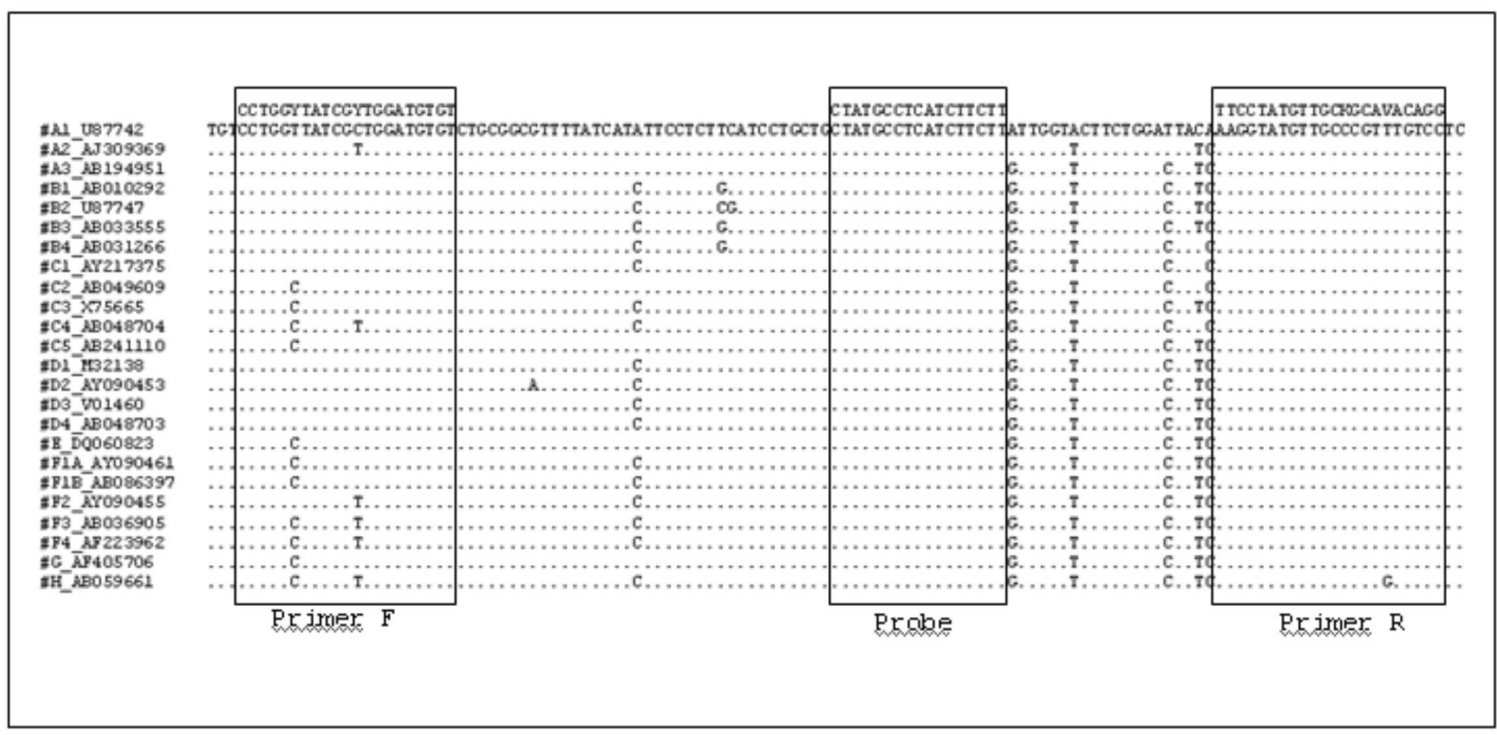

Fig. 1 - Alignment of different HBV genotypes and subgenotype strains from GenBank showing the localization of primers and probe selected for the HBV qPCR.
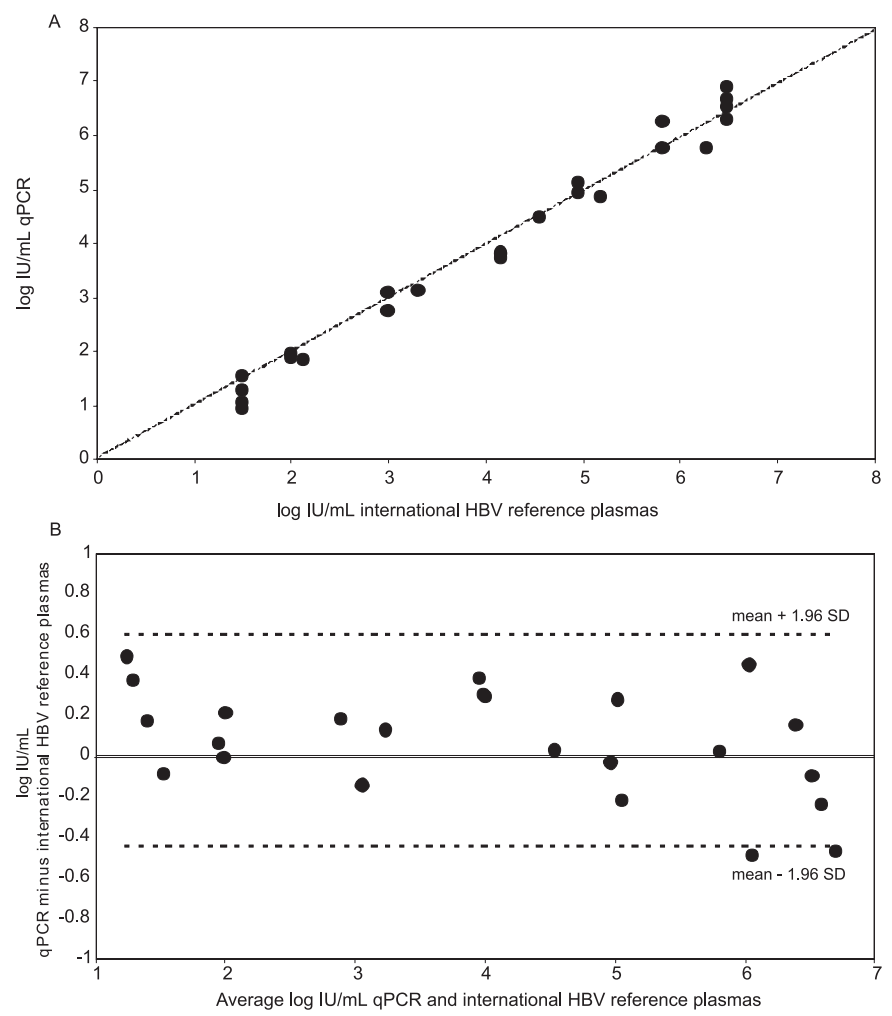

Fig. 2 - Scatter plot (A) and Bland-Altman (B) of the comparisons between qPCR and International HBV reference plasmas. In Fig. A, the dotted line refers to diagonal $(\mathrm{y}=\mathrm{x})$.

Influence of Internal Control primers and probe was tested by parallel reactions performed with and without them. HBV viral load was the same in both reactions showing no competition. Besides, internal control was detected in all samples with viral load below $10^{6} \mathrm{IU} / \mathrm{mL}$.

Reproducibility: Interassay variability was determined by running the samples for 12 consecutive days and intra-assay variability was evaluated by running 10 determinations for each sample. Results of viral load means, standard deviation (SD) and coefficient of variation (CV) are shown in Table 1. One sample (B) was diluted to $1.40 \log \mathrm{IU} / \mathrm{mL}$ and could not be detected in all runs, but it was below the established detection limit of $1.70 \log \mathrm{IU} / \mathrm{mL}$.

Table 1

Reproducibility of real time assay for hepatitis B virus (HBV) detection

\begin{tabular}{lcccc}
\hline & n times & $\begin{array}{c}\text { Input HBV } \\
\text { DNA } \\
(\log \text { IU/mL) }\end{array}$ & $\begin{array}{c}\text { Observed } \\
\text { HBV DNA } \\
(\log \text { IU/mL) } \\
\text { Mean (SD) }\end{array}$ & CV $^{\mathrm{a}, \mathrm{b}}$ \\
\hline Interassay & 12 & 7.25 & $7.13(0.07)$ & 0.01 \\
High (pure) - A & 12 & 7.40 & $7.29(0.07)$ & 0.01 \\
High (pure) - B & 12 & 2.25 & $2.23(0.31)$ & 0.14 \\
Low $\left(10^{-5}\right)$ - A & 10 & 1.40 & $1.33(0.35)$ & 0.26 \\
Low $\left(10^{-6}\right)$ - B & 10 & 7.25 & $7.00(0.04)$ & 0.01 \\
Intra-assay & 10 & 7.40 & $6.79(0.05)$ & 0.01 \\
High (pure) - A & 10 & 4.25 & $4.34(0.08)$ & 0.02 \\
High (pure) - B & 10 & 4.40 & $4.14(0.04)$ & 0.01 \\
Intermediate $\left(10^{-3}\right)$ - A & 10 & 2.25 & $2.73(0.16)$ & 0.06 \\
Intermediate $\left(10^{-3}\right)$ - B & 10 & & & \\
Low $\left(10^{-5}\right)$ - A & $1.63(0.15)$ & 0.09 \\
Low $\left(10^{-6}\right)$ - B & 8 & 1.40 & &
\end{tabular}

${ }^{\mathrm{a}}$ mean $\mathrm{CV}$ interassay: $0.12 ;{ }^{\mathrm{b}}$ mean $\mathrm{CV}$ intra-assay: 0.03

Specificity: None of the 40 samples from healthy blood donors had detectable results for HBV DNA, tested in duplicate. Negative controls (NC) were also processed in every reaction in a proportion of one $\mathrm{NC}$ for every five-tested sample. Negative results were obtained every time for those samples. 

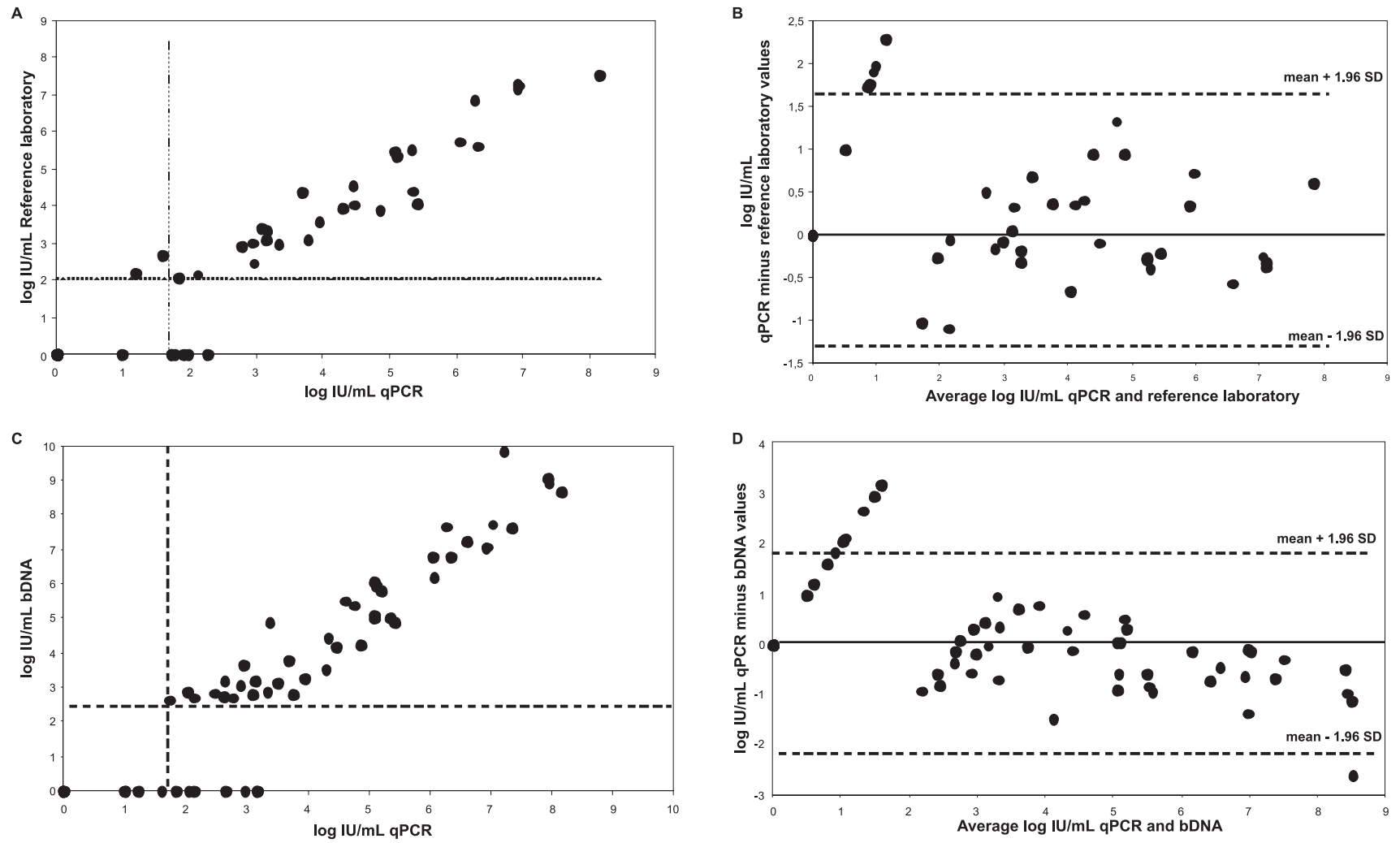

Fig. 3 - Comparisons between qPCR and reference laboratory (A and B) and bDNA (C and D). In Fig. A and C (Scatter plots), the dotted lines refer to minimum detection limit for each method while Figures B and D show Bland-Altman comparisons between the two methods.

Correlation between real time and other HBV DNA assays: The HBV DNA real-time PCR detection assay was compared with Versant HBV DNA Assay version 3.0 (bDNA - Siemens Medical Solutions Diagnostics, Tarrytown, NY, USA) $(n=58)$ and samples were also sent to a reference laboratory (Quest diagnostics, San Juan Capistrano, CA, USA) $(n=56)$. The log of viral load values $(I U / m L)$ obtained was plotted against values obtained from reference laboratory (Fig. 3A) and bDNA (Fig. 3C). It is noteworthy that some samples were detected only by the qPCR here described. Linear correlation coefficient based on only detectable (or undetectable) viral loads by both methods were high $(r=0.984$ for reference laboratory and $r=0.966$ for bDNA). In Bland-Altman plots (Fig. 3B and 3D), only one sample with high viral load in Figure 3D had absolute difference between qPCR and bDNA, higher than expected. This sample was genotype A and had a viral load of $9.82 \log \mathrm{IU} / \mathrm{mL}$, above our linear range, and should be diluted. Other samples that exceed $95 \%$ limits of agreement correspond to low viral load samples, which were detected only by qPCR method. Samples with different viral load levels were tested for each genotype.

\section{DISCUSSION}

HBV viral load measuring is a very important tool for monitoring HBV infected patients. There is an increasing trend for the use of combination of nucleotide analogs, which lead to a fast dynamic of viral load. It is expected that monitoring the HBV viral load together with the detection of resistance related mutations in the HBV genome will be able to provide clinicians with important guidelines for the HBV treatment.
The most direct and reliable measurement of viral replication is HBV DNA quantification that can replace other indirect methods to assess the efficacy of antiviral therapy used to treat HBV infected patients, such as serologic markers or measurement of liver enzyme function. Histology is adequate to evaluate the efficacy of a treatment, however, lacks the ability to discriminate rapidly any difference at multiple time points in clinical trials, comparing active drugs or combination therapy. Monitoring the HBV viral load can predict the evolution to cirrhosis and hepatocellular carcinoma $^{6}$, as well as a rapid and sustained response to treatment, as a predictive factor for a favorable treatment outcome. It can also provide an early detection of treatment failure that may be related to poor adherence to therapy or selection of a resistant virus. The likelihood of resistance to nucleos $(\mathrm{t})$ ide analogues is very low when HBV-DNA level is undetectable during therapy and increases proportionally to the HBV-DNA level ${ }^{21}$.

An assay with a lower limit of detection of $10^{3} \mathrm{IU} / \mathrm{mL}$ may be sufficient to monitor and manage the patient but, in some instances a more sensitive assay with a lower limit of detection of the order of $10^{1} \mathrm{IU} / \mathrm{mL}$ may be required to ensure detection of the emergence of resistance as early as possible. Our results have shown that we could detect samples with viral load below $50 \mathrm{IU} / \mathrm{mL}$. An example can be seen in Table 1, where Sample B - Low $\left(10^{-6}\right)$ could not be detected in $2 / 12$ times in the interassay test and in $2 / 10$ times in the intra-assay test. A dynamic range of quantification of at least $5 \log _{10}$ is also recommended and samples with an HBV-DNA level above the upper limit of detection of the assay should be diluted and retested to provide an end point. For all of these reasons, real-time PCR quantification assays are strongly recommended 


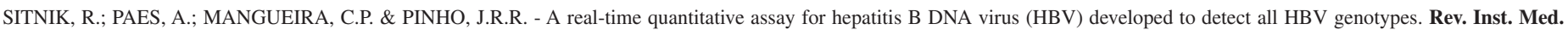
Trop. Sao Paulo, 52(3):119-24, 2010 .

over other technologies, especially in clinical trials, because they are very sensitive and have a broad dynamic range of quantification ${ }^{1,13,14,19,21}$.

Early predictors of the treatment efficacy at week 24 include (1) complete virologic response, defined as a decrease in HBV DNA to $<60$ $\mathrm{IU} / \mathrm{mL}$; (2) partial virologic response (HBV DNA 60 to < $2000 \mathrm{IU} / \mathrm{mL}$ ); or (3) inadequate virologic response (HBV DNA $\geq 2000 \mathrm{IU} / \mathrm{mL}$ ). Treatment recommendations vary depending on which of these categories a patient falls into. For patients who have an ideal response to therapy (complete virologic response), the panel recommends maintaining treatment with no change and broadening the interval for monitoring. Treatment should be continued without change for patients who have an adequate response to therapy (partial virologic response) and monitoring should be more frequent. For patients who have a suboptimal response or no response to therapy, the panel recommends switching to or adding alternative therapy with no overlapping resistance mutations and continuing to monitor frequently ${ }^{10}$.

Although we have only tested this assay with samples harboring genotypes $\mathrm{A}$ to $\mathrm{F}$ during the validation process, the primer sequences chosen were also covered for genotypes $\mathrm{G}$ and $\mathrm{H}$, which are more similar to genotypes A and F, respectively. Afterwards, the protocol was established in the routine laboratory and more than 1,500 clinical samples were already analyzed, including genotypes A to G. Proficiency test samples (Hepatitis Viral Load Survey from the College of American Pathologists - CAP and Molecular Biology Panel from ControlLab, SBPC/ML) were also analyzed with satisfactory results in the last two years.

In Brazil, only a few commercial HBV quantification assays are available; and several in house assays described before have some limitations, such as lack of internal control, a small linear range or allowing analysis of only a few HBV genotypes ${ }^{1,13,14,20}$.

When conducting this work, we were able to compare our test with the only commercial available kit (bDNA) and it was possible to verify its low sensibility, linked to the principle of the method. Nowadays, other commercial kits have been released, such as the Cobas Taqman HBV test (Roche) and Abbott Real Time HBV assay, but these kits are more expensive and not commercially available in many countries. Otherwise, this is an open protocol that allows HBV quantitation in resource-limited settings, providing a cheap and effective alternative to existing HBV assays. It has already been shown in other studies that in house testing for HCV and HIV detection and quantitation ${ }^{7,8,22,24,27}$ can be used routinely, provided high level quality control rules are followed.

An underestimation of the HBV viral load of genotype F samples with the Cobas Monitor PCR system has been reported ${ }^{12}$. As genotype $\mathrm{F}$ is mainly present in Central and South America and is relatively common among our patients in this case ${ }^{25}$, quantification of this genotype is very important in Brazil. In the COBAS Taqman HBV Test this problem seems to be solved and it equally amplifies genotypes A-G. The linear range of this test is from 29 to $1.1 \times 10^{8} \mathrm{IU} / \mathrm{mL}$ and the probes are directed to the pre-core/core region of $\mathrm{HBV}^{2,29}$.

The Abbott Real Time HBV kit is also a real time PCR based kit, all HBV genotypes (A-H) can be adequately detected, results in IU/mL or copies $/ \mathrm{mL}$, dynamic range from 10 to $10^{9} \mathrm{IU} / \mathrm{mL}$. The probes are in the $\mathrm{S}$ region of HBV genome ${ }^{28}$.
The standardization of quantification units is another important issue when measuring HBV viral load. Serum HBV-DNA levels are reported in many different units depending on the method used and the manufacturer of the assay (eg, copies/mL, genome equivalents - Eq/mL, mega-equivalents - MEq/mL, or international units -IU/mL). The World Health Organization has defined an international standard for HBV DNA nucleic acid amplification techniques that has been used to calibrate the IU/mL. Several HBV-DNA quantification assays that are available have been normalized to the World Health Organization international standard, such as the Abbott Real Time HBV kit and the COBAS Taqman HBV Test. Serum HBV-DNA levels should now be expressed universally in IU/mL in all available assays to ensure comparability between the assays, between different trials in which different assays have been used, and to allow the creation of guidelines that can be applied to whatever assay was used ${ }^{21}$.

In the test described here, many limitations of other methods were considered. Since conserved regions were chosen from the alignments of all HBV genotypes (A-H) during primer and probe design; and genotypes A-F infected patients were tested, this assay showed efficacy to amplify all genotypes circulating in Brazil. The use of an internal control, extracted together with the sample, is able to detect the presence of inhibitors in the sample. The standard curve was normalized to IU/mL, and this qPCR is sensitive, accurate and reproducible allowing the quantification of HBV DNA, particularly useful for following chronic HBV carriers. The assay was implemented in the diagnostic routine from a clinical laboratory and has proved to be highly cost efficient.

\section{RESUMO}

\section{Ensaio quantitativo em tempo real para o DNA do vírus da hepatite B (HBV) desenvolvido para detectar todos os genótipos do HBV}

O vírus da Hepatite B (HBV) é uma das principais causas de doença crônica do fígado no mundo. Além do genótipo, a análise quantitativa do HBV é amplamente utilizada para monitorar a progressão da doença e o tratamento. Em locais com recursos escassos, métodos baratos para o monitoramento da carga viral são desejáveis e, em países em desenvolvimento, sua utilidade já foi demonstrada para outros vírus, como o da Hepatite C e HIV. Neste trabalho, descrevemos a validação de um teste de PCR em Tempo Real para a quantificação do DNA do HBV utilizando sondas Taqman/MGB. Os oligos e sondas foram escolhidos usando um alinhamento contendo seqüências de todos os genótipos do HBV para garantir uma amplificação igual de todos eles. O teste possui um controle interno e foi padronizado com um painel internacional de HBV. Sua eficácia foi testada comparando-se os resultados com outros dois métodos: Versant HBV DNA Assay 3.0 (bDNA, Siemens, NY, USA) e outro PCR em tempo real realizado em um laboratório de referência. As reprodutibilidades intra e inter-ensaio foram determinadas e a média dos valores de $\mathrm{CV}$ obtidos foram de 0,12 e 0,09 , respectivamente. $\mathrm{O}$ teste foi validado com uma ampla faixa dinâmica e amplificou com eficiência os diferentes genótipos de HBV, fornecendo uma boa opção para a quantificação de rotina do DNA do $\mathrm{HBV}$, com um protocolo barato e confiável.

\section{ACKNOWLEDGMENTS}

We would like to thank the Molecular Pathology Department from Hospital Israelita Albert Einstein, in particular: Cinthia Bachir Moyses, 
SITNIK, R.; PAES, A.; MANGUEIRA, C.P. \& PINHO, J.R.R. - A real-time quantitative assay for hepatitis B DNA virus (HBV) developed to detect all HBV genotypes. Rev. Inst. Med. Trop. Sao Paulo, 52(3):119-24, 2010.

Cláudia Huerta de Nardi Graça, Gregorio Tadeu Fernando Dastoli, Leticia Oyakawa, Liana Carballo Menezes, and Rubia Anita Ferraz Santana. We are also thankful to Michele Gomes-Gouvêa of the Tropical Medicine Institute/FMUSP.

Funding: Instituto de Ensino e Pesquisa and Instituto de Responsabilidade Social from Hospital Israelita Albert Einstein, São Paulo, SP, Brazil. The funders had no role in study design, data collection and analysis, decision to publish, or preparation of the manuscript.

\section{REFERENCES}

1. Abe A, Inoue K, Tanaka T, Kato J, Kajiyama N, Kawaguchi R, et al. Quantitation of Hepatitis B virus genomic DNA by real-time detection PCR. J Clin Microbiol. 1999;37:2899-903.

2. Allice T, Cerutti F, Pittaluga F, Varetto S, Gabella S, Marzano A, et al. COBAS AmpliPrepCOBAS TaqMan hepatitis B virus (HBV) test: a novel automated real-time PCR assay for quantification of HBV DNA in plasma. J Clin Microbiol. 2007;45:828-34.

3. Araujo NM, Mello FC, Yoshida CF, Niel C, Gomes SA. High proportion of subgroup A' (genotype A) among Brazilian isolates of Hepatitis B virus. Arch Virol. 2004;149:1383-95.

4. Bland JM, Altman DG. Statistical methods for assessing agreement between two methods of clinical measurement. Lancet. 1986;1:307-10

5. Bottecchia M, Souto FJ, Ó KM, Amendola M, Brandão CE, Niel C, et al. Hepatitis B virus genotypes and resistance mutations in patients under long term lamivudine therapy: characterization of genotype G in Brazil. BMC Microbiol. 2008;22:8-11.

6. Chen CJ, Yang HI, Su J, Jen CL, You SL, Lu SN, et al. Risk of hepatocellular carcinoma across a biological gradient of serum hepatitis B virus DNA level. JAMA. 2006;295:65-73.

7. Drexler JF, Kupfer B, Petersen N, Grotto RM, Rodrigues SM, Grywna K, et al. A novel diagnostic target in the hepatitis C virus genome. PLoS Med. 2009;6:e31.

8. Fiscus SA, Cheng B, Crowe SM, Demeter L, Jennings C, Miller V, et al. HIV-1 viral load assays for resource-limited settings. PLoS Med. 2006;3:e417.

9. Gordillo RM, Gutiérrez J, Casal M. Evaluation of the COBAS TaqMan 48 real-time PCR system for quantitation of hepatitis B virus DNA. J Clin Microbiol. 2005;43:3504-7.

10. Keeffe EB, Zeuzem S, Koff RS, Dieterich DT, Esteban-Mur R, Gane EJ, et al. Report of an International Workshop: roadmap for management of patients receiving oral therapy for chronic hepatitis B. Clin Gastroenterol Hepatol. 2007;5:890-7.

11. Kessler HH, Pierer K, Dragon E, Lackner H, Santner B, Stünzner D, et al. Evaluation of a new assay for HBV DNA quantitation in patients with chronic hepatitis B. Clin Diagn Virol. 1998;9:37-43.

12. Laperche S, Thibault V, Bouchardeau F, Alain S, Castelain S, Gassin M, et al. Expertise of laboratories in viral load quantification, genotyping, and precore mutant determination for hepatitis B virus in a multicenter study. J Clin Microbiol. 2006;44:3600-7.

13. Lole, KS, Arankalle VA. Quantitation of Hepatitis B virus DNA by real-time PCR using internal amplification control and dual TaqMan MGB probes. J Virol Met. 2006;135:83-90.

14. Mukaide M, Tanaka Y, Katayose S, Tano H, Murata M, Hikata M, et al. Development of real-time detection direct test for hepatitis B virus and comparison with two commercial testes using the WHO international standard. J Gastroenterol Hepatol. 2003; 18:1264-71
15. Norder H, Hammas B, Lee SD, Bile K, Couroucé AM, Mushahwar IK, et al. Genetic relatedness of hepatitis $\mathrm{B}$ viral strains of diverse geographical origin and natural variations in the primary structure of the surface antigen. J Gen Virol. 1993;74:1341-8.

16. Norder H, Couroucé AM, Magnius LO. Complete genomes, phylogenic relatedness and structural proteins of six strains of the hepatitis B virus, four of which represent two new genotypes. Virology. 1994;198:489-503.

17. Norder H, Couroucé AM, Coursaget P, Echevarria JM, Lee SD, Mushahwar IK, et al. Genetic diversity of hepatitis B virus strains derived worldwide: genotypes, subgenotypes, and HBsAg subtypes. Intervirology. 2004;47:289-309.

18. Okamoto H, Tsuda F, Sakugawa H, Sastroewignjo RI, Imai M, Miyakawa Y, et al. Typing hepatitis B virus by homology in nucleotide sequence: comparison of surface antigen subtypes. J Gen Virol. 1988;69:2575-83.

19. Pas SD, Fries E, de Man RA, Osterhaus ADME, Niesters HGM. Development of a quantitative real-time detection assay for hepatitis B virus DNA and comparison with two commercial assays. J Clin Microbiol. 2000;38:2897-901.

20. Pas SD, Niesters HGM. Detection of HBV DNA using real time analysis. J Clin Virol. 2002;25:93-4.

21. Pawlotsky JM, Dusheiko G, Hatzakis A, Lau D, Lau G, Liang TJ, et al. Virologic monitoring of hepatitis $\mathrm{B}$ virus therapy in clinical trials and practice: recommendations for a standardized approach. Gastroenterology. 2008;134:405-15.

22. Phillips AN, Pillay D, Miners AH, Bennett DE, Gilks CF, Lundgren JD. Outcomes from monitoring of patients on antiretroviral therapy in resource-limited settings with viral load, CD4 cell count, or clinical observation alone: a computer simulation model. Lancet. 2008; 371:1443-51

23. Ribeiro NR, Campos GS, Angelo AL, Braga EL, Santana N, Gomes MM, et al. Distribution of hepatitis B virus genotypes among patients with chronic infection. Liver Int 2006;26:636-42.

24. Roth WK, Weber M, Seifried E. Feasibility and efficacy of routine PCR screening of blood donations for hepatitis C virus, hepatitis B virus, and HIV-1 in a blood-bank setting. Lancet. 1999;353:359-63.

25. Sitnik R, Pinho JR, Bertolini DA, Bernardini AP, da Silva LC, Carrilho FJ. Hepatitis B virus genotypes and precore and core mutants in Brazilian patients. J Clin Microbiol. 2004;42:2455-60.

26. Sitnik R, Sette H Jr, Santana RA, Menezes LC, Graça CH, Dastoli GT, et al. Hepatitis B virus genotype $\mathrm{E}$ detected in Brazil in an African patient who is a frequent traveler. Braz J Med Biol Res. 2007;40:1689-92.

27. Stramer SL, Glynn SA, Kleinman SH, Strong DM, Caglioti S, Wright DJ, et al. Detection of HIV-1 and HCV infections among antibody-negative blood donors by nucleic acid-amplification testing. N Engl J Med. 2004;351:760-8.

28. Thibault V, Pichoud C, Mullen C, Rhoads J, Smith JB, Bitbol A, et al. Characterization of a new sensitive PCR assay for quantification of viral DNA isolated from patients with hepatitis B virus infections. J Clin Microbiol. 2007;45:3948-53.

29. Weiss J, Wu H, Farrenkopf B, Schultz T, Song G, Shah S, et al. Real-Time TaqMan PCR detection and quantitation of HBV genotypes A-G with the use of an internal quantitation standard. J Clin Virol. 2004;30:86-93.

30. Yao JD, Beld MG, Oon LL, Sherlock CH, Germer J, Menting S, et al. Multicente evaluation of the VERSANT hepatitis B virus DNA 3.0 assay. J Clin Microbiol. 2004:42:800-6.

Received: 20 August 2009

Accepted: 22 April 2010 